\title{
Harmoni Sosial dalam Tradisi Sedekah Bumi Masyarakat Desa Pancur Bojonegoro
}

\author{
M.Thoriqul Huda \\ Institut Pesantren KH. Abdul Chalim Mojokerto \\ huda90.ikhac@gmail.com
}

\begin{abstract}
Abstrak
Culture and society are two things that cannot be separated, both are closely related and go hand in hand. Sedekah bumi is one of the cultural agrarian societies that continues to be maintained from time to time, including the culture of sedekah bumi carried out by the people of Pancur Temayang village in Bojonegoro. Sedekah bumi tradition has become a routine part of the routine carried out every year by the Pancur community as a form of appreciation for God who has bestowed His fortune through abundant crops so that people can fulfill their daily needs. In conducting this research, researchers used a qualitative method with an ethnographic approach as a basis for conducting observations in the field because researchers needed to enter directly into the object of research to explore the meaning and value of tradition understood by the Pancur village community in carrying out the sedekah bumi tradition. Explained that sedekah bumi carried out by the people of Pancur village has several value benefits, including sociological values, namely with the existence of these activities, the social ties of people from various groups unite. Theological value, namely the implementation of the sedekah bumi as an expression of gratitude for maintaining good relations with God. Ecological value, the existence of sedekah bumi carried out in the village spring, give confidence to the community that the existence of the village spring must be preserved, and the existence of the surrounding ecosystem must also be maintained. In addition, sedekah bumi tradition also received a variety of responses from the village community, some agreed and some did not agree with the implementation of this tradition.
\end{abstract}


[Budaya dan masyarakat merupakan dua hal yang tidak bisa dipisahkan, keduanya saling erat berkaitan dan berjalan beriringan. Sedekah bumi adalah salah satu budaya masyarakat agraris yang terus dijaga dari masa ke masa, termasuk budaya sedekah bumi yang dilakukan oleh masyarakat desa Pancur Temayang Bojonegoro. Tradisi sedekah bumi sudah menjadi bagian rutinitas rutin yang dilakukan setiap tahun oleh masyarakat Pancur sebagai bentuk pengahargaan terhadap Tuhan yang telah melimpahkan rejeki-Nya melalui hasil panen yang melimpah sehingga masyarakat dapat memenuhi kebutuhan hidupnya. Dalam melakukan penelitian ini, peneliti menggunakan metode kualitatif dengan pendekatan etnografi sebagai pijakan untuk melakukan observasi di lapangan hal ini dikarenakan peneliti perlu masuk secara langsung ke objek penelitian untuk mendalami makna serta nilai tradisi yang dipahami masyarakat desa Pancur dalam melaksanakan tradisi sedekah bumi, adapun hasil penelitian menjelaskan bahwa sedekah bumi yang dilakukan oleh masyarakat desa Pancur mempunyai beberapa manfaat nilai, diantaranya adalah nilai sosiologis, yakni dengan adanya kegiatan tersebut, ikatan social masyarakat dari berbagai golongan bersatu. Nilai teologis, yakni pelaksanaan sedekah bumi sebagai ungkapan syukur untuk menjaga hubungan baik dengan Tuhan. Nilai ekologis, keberdaan sedekah yang dilaksanakan di sendang desa, memberikan kepercayaan pada masyarakat bahwa keberadaan sendang desa harus tetap dilestarikan, dan keberadaan ekosistem di sekitarnya juga harus dijaga. Selain itu tradisi sedekah bumi juga mendapatkan respon yang beragam dari masyarakat desa, ada yang setuju dan ada juga yang kurang setuju dengan pelaksanaan tradisi ini.]

Keywords; Sedekah Bumi, Value and Meaning

\section{Pendahuluan}

Kehidupan beragama pada dasarnya merupakan kepercayaan terhadap adanya kekuatan gaib, luar biasa atau supranatural yang berpengaruh dalam kehidupan individu dan masyarakat. Hampir seluruh suku di dunia memiliki keyakinan terhadap adanya kekuatan goib dan 
mahkluk halus. Keyakinan itu bisa berupa kepercayaan terhadap peristiwa yang terjadi di alam, terhadap dewa-dewa atau terhadap adanya Tuhan yang maha esa dan kuasa. ${ }^{1}$ Kepercayaan itu menimbulkan perilaku tertentu seperti berdo'a, memuja, dan menimbulkan sikap mental tertentu, seperti rasa takut, rasa optimis, rasa pasrah dari individu dan masyarakat yang mempercayainya. Karena itu, keinginan, petunjuk dan ketentuan-ketentuan ghoib harus dipatuhi dan ditaati kalau manusia dan masyarakat ingin kehidupan ini berjalan dengan baik dan selamat. ${ }^{2}$ Kehidupan beragama seperti di atas adalah kenyataan hidup manusia yang ditemukan sepanjang sejarah masyarakat. Ketergantungan masyarakat pada kekuatan gaib atau yang suci ditemukan pada zaman purba sampai ke zaman sekarang. Atas dasar hubungan terhadap kepercayan yang diyakini kebenarannya, maka ia menjadi kepercayaan keagamaan atau kepercayaan religius.

Mengadakan upacara pada momen-momen tertentu seperti perkawinan, larung sesaji dan sedekah laut, adalah kegiatan yang berlangsung dari dahulu kala sampai zaman sekarang ini. Upacaraupacara ini dalam agama dinamakan tindakan religi atau ritual, yang mempunyai tempat tersendiri dan menggunakan sesuatu yang dianggap sakral ${ }^{3}$. Bagi Durkheim menimbulkan suatu dampak kewajiban untuk berperilaku keagamaan, ${ }^{4}$ sedangkan menurut koentjaraningrat implikasi pengalaman terhadap yang suci tersebut menimbulkan tindakan-tindakan religi. ${ }^{5}$ Tindakan keagamaan ini rutin dilakukan oleh manusia dalam rangka menjaga hubungan baik dengan yang dianggap suci, Rudolf Otto mengatakan bahwa yang suci tersebut adalah kekuatan tertinggi. Apa yang terlihat di dalamnya adalah sesuatu yang tak terselami dan mengatasi

\footnotetext{
${ }^{1}$ Nur Syam, Islam Pesisir (Yogyakarta: LKIS, 2005), 108.

${ }^{2}$ Muhamad Damami, Makna Agama dalam Masyarakat Jawa (Yogyakarta: LESFI, 2002), 57.

${ }^{3}$ Bustanuddin Agus, Agama dalam kehidupan Manusia, Pengantar Antropologi Agama (Jakarta: Raja Grafindo Persada, 2007).

${ }^{4}$ Koentjaraningrat, Pengantar Antropologi; Pokok - Pokok Etnografi (Jakarta: Rineka Cipta, 1998), 201.

${ }^{5}$ Koentjaraningrat, Pengantar Ilmu Antrpologi (Jakarta: Rineka Cipta, 1990), 377.
} 
semua mahluk, sehingga menimbulkan implikasi ketidakberdayaan bagi penganutnya $^{6}$. Bagi Durkheim berdampak pada kewajiban untuk berperilaku keagamaan. $^{7}$

Namun tidak bisa dipungkiri bahwa budaya yang dilakukan oleh masyarakat tidak akan pernah lepas dari pengaruh kebudayaan luar serta tantangan perubahan sosial masyarakat yang semakin dinamis, artinya perubahan yang terjadi pada masyakarat memberikan pengaruh terhadap terjadinya perubahan pada budaya itu sendiri, ${ }^{8}$ perubahan sosial masyarakat yang dimaksud dapat menggeser tata budaya yang sudah ada, mentransformasikannya, menggantikannya, atau menambahkan yang baru yang disandingkan dengan budaya yang sudah ada. ${ }^{9}$ Dialektika budaya yang semacam ini akan senantiasa terus terjadi dan tidak akan pernah usai selama manusia masih menjalankan perannya sebagai mahluk sosial, bergerak dari satu generasi ke generasi berikutnya, oleh karena itu budaya bukanlah suatu praktik tradisi yang bersifat dinamis, akan tetapi selalu mengalami perubahan sesuai dengan kondisi sosial masyarakat. ${ }^{10}$ Namun demikian di satu sisi budaya masyarakat selalu memberikan ruang bagi tiap- tiap individu untuk berinteraksi dengan individu lain, sehingga menciptakan harmoni sosial ditengah masyarakat, menghilangkan fragmen- fragmen yang ada di masyarakat serta dapat menumbuhkan nilai- nilai kerjasama di masyarakat yang sudah mulai luntur. ${ }^{11}$

'Thomas F O'dea, Sosiologi Agama; Suatu Pengantar Awal (Jakarta: CV Rajawali, 1992), 3839

${ }^{7}$ Koentjaraningrat, Pengantar Antropologi; Pokok - Pokok Etnografi (Jakarta: Rineka Cipta, 1998), 201.

${ }^{8}$ Harsojo, Pengantar Antropologi (Jakarta: Abardi, 1984), 154.

${ }^{9}$ Masimambow, Koentjaraningrat dan Antropologi di Indonesia (Jakarta: Yayasan Obor Indonesia, 1997), 9.

${ }^{10}$ Sjafri Sairin, Perubahan Sosial Masyarakat Indonesia (Yogyakarta: Pustaka Pelajar, 2002), 184.

${ }^{11}$ Samsul Ode, "Budaya Lokal Sebagai Media Resolusi dan Pengendalian Konflik di Provinsi Maluku”, Jurnal POLITIKA, Vol. 6 No. 2 tahun 2015, 93-100. 


\section{Sedekah Bumi Sebagai Bagian dari Budaya}

Sedekah bumi adalah suatu upacara adat yang melambangkan rasa syukur manusia terhadap Tuhan yang maha esa yang telah memberikan rezeki melalui tanah/bumi berupa segala bentuk hasil bumi. Upacara ini sebenarnya sangat populer di Indonesia khususnya Pulau Jawa, namun dengan berbagai versi dan cara. Sedekah bumi merupakan ucapan rasa syukur kepada rezeki yang sudah di terima, dan permohonan rasa harap akan rezeki yang melimpah pada masa depan. Pengertian lain dari sedekah bumi adalah salah satu tradisi masyarakat Jawa yang masih eksis dan menjadi kegiatan rutin masyarakat Jawa hingga kini, sedekah bumi diwariskan secara turun-temurun dari nenek moyang terdahulu dan kebanyakan ritual ini dilakukan oleh masyarakat agraris. ${ }^{12}$

Setiap daerah mempunyai konsep tersendiri tentang tatacara pelaksanaan sedekah bumi, hal ini disesuaikan dengan tradisi nenek moyang yang sudah berjalan secara turun-temurun. Dalam rangakian acara tradisi sedekah bumi secara umum dilakukan sebagai bentuk rasa syukur atas nikmat yang sudah diperoleh warga, sehingga dalam pelaksanaanya tidak luput dari berbagai macam simbol sebagai bentuk ucapan syukur tersebut. Dalam tradisi sedekah bumi selalu disertai dengan adanya kepercayaan masyarakat terhadap hal gaib yang ada di luar dimensi manusia. Sedekah bumi merupakan bagian dari kebudayaan masyarakat, hal ini dikarenakan dalam pelaksanaan tradisi sedekah bumi, memenuhi berbagai unsur - unsur sebagai sebuah budaya.

Masyarakat dan kebudayaan adalah hal yang tidak dapat dipisahkan. Masyarakat adalah kelompok manusia yang telah hidup dan bekerja bersama cukup lama, sehingga mereka dapat mengatur hidup mereka dan menganggap diri mereka sebagai suatu kesatuan sosial dengan batas atas yang sudah dirumuskan. ${ }^{13}$ Kebudayaan adalah khasanah pengetahuan bersifat abstrak milik masyarakat. Budaya adalah suatu cara hidup yang berkembang dan dimiliki bersama oleh sekelompok orang dan

${ }^{12}$ Widodo, dkk, Kamus Ilmiah Populer; dilengkapi EYD dan Pembentukan Istilab (Yogyakarta: Absolut, 2002), 723.

13Soerjono Soekanto, Sosiologi Suatu Pengantar (Jakarta: Raja Grafindo Persada, 2006), 22. 
diwariskan dari generasi ke generasi. Budaya terbentuk dari banyak unsur yang rumit, termasuk sistem agama dan politik, adat istiadat, bahasa, perkakas, pakaian, bangunan, dan karya seni, Bahasa, sebagaimana juga budaya, merupakan bagian tak terpisahkan dari diri manusia, sehingga banyak orang cenderung menganggapnya diwariskan secara genetis. Ketika seseorang berusaha berkomunikasi dengan orang-orang yang berbeda budaya dan menyesuaikan perbedaan-perbedaannya, membuktikan bahwa budaya itu dipelajari. Budaya adalah suatu pola hidup menyeluruh. Budaya bersifat kompleks, abstrak, dan luas. Dengan demikian, budayalah yang menyediakan suatu kerangka yang koheren untuk mengorganisasikan aktivitas seseorang dan memungkinkannya meramalkan perilaku orang lain. Kebudayaan sangat erat hubungannya dengan masyarakat. Bahwa segala sesuatu yang terdapat dalam masyarakat ditentukan oleh kebudayaan yang dimiliki oleh masyarakat itu sendiri.

Secara umum budaya sendiri atau kebudayaan berasal dari bahasa sansekerta yaitu buddhayah, yang merupakan bentuk jamak dari buddhi (budi atau akal) ${ }^{14}$ diartikan sebagai hal- hal yang berkaitan dengan budi dan akal manusia, dalam bahasa inggris kebudayaan disebut culture $^{15}$ yang berasal dari kata latin colere yaitu mengolah atau mengerjakan dapat diartikan juga sebagai mengolah tanah atau bertani, kata culture juga kadang sering diterjemahkan sebagai "Kultur" dalam bahasa Indonesia ${ }^{16}$.

Seorang antopolog Inggris Edward B. Taylor (1832-1917) mengatakan bahwa Kultur adalah keseluruhan yang kompleks termasuk didalamnya pengetahuan, kepercayaan, kesenian, moral, hukum adat dan

\footnotetext{
${ }^{14}$ Elly M. Setiadi, Ilmu Sosial Dasar (Jakarta: Kencana, 2012), 27.

${ }^{15}$ Martin H Manser, Oxford Advanced Learns Dictionary (New York: Oxford University Press, 2006), 357.

${ }^{16}$ Departemen Pendidikan dan Kebudayaan, Kamus Babasa Besar Indonesia (Jakarta: PT. Balai Pustaka, 2005), 149.
} 
segala kemampuan dan kebiasaan lain yang diperoleh manusia sebagai seorang anggota masyarakat ${ }^{17}$.

Salah seorang guru besar antropologi Indonesia Kuntjaraningrat berpendapat bahwa "kebudayaan" berasal dari kata sansekerta buddhayah bentuk jamak dari buddhi yang berarti budi atau akal, sehingga menurutnya kebudayaan dapat diartikan sebagai hal- hal yang bersangkutan dengan budi dan akal, ada juga yang berpendapat sebagai suatu perkembangan dari majemuk budi- daya yang artinya daya dari budi atau kekuatan dari akal ${ }^{18}$.

1. Sistem Bahasa

Bahasa merupakan sarana bagi manusia untuk memenuhi kebutuhan sosialnya untuk berinteraksi atau berhubungan dengan sesamanya. Dalam ilmu antropologi, studi mengenai bahasa disebut dengan istilah antropologi linguistik. kemampuan manusia dalam membangun tradisi budaya, menciptakan pemahaman tentang fenomena sosial yang diungkapkan secara simbolik, dan mewariskannya kepada generasi penerusnya sangat bergantung pada bahasa. Dengan demikian, bahasa menduduki porsi yang penting dalam analisa kebudayaan manusia.

2. Sistem Pengetahuan

Sistem pengetahuan dalam kultural universal berkaitan dengan sistem peralatan hidup dan teknologi karena sistem pengetahuan bersifat abstrak dan berwujud di dalam ide manusia. Sistem pengetahuan sangat luas batasannya karena mencakup pengetahuan manusia tentang berbagai unsur yang digunakan dalam kehidupannya. Banyak suku bangsa yang tidak dapat bertahan hidup apabila mereka tidak mengetahui dengan teliti pada musim apa berbagai jenis ikan pindah ke hulu sungai. Selain itu, manusia tidak

${ }^{17}$ Edward B. Tylor, Primitive Culture; Research into the Development of Mythology, Philosophy, Religion, Language, Art and Custom (1874), dalam Koenjtaraningrat, Sejarah Teori Antropologi I (Jakarta: UI Press, 1987), 48.

${ }^{18}$ Koentjaraningrat, Kebudayaan, Mentalitas dan Pembangunan (Jakarta: Gramedia Pustaka Utama, 1993), 9. 
dapat membuat alat-alat apabila tidak mengetahui dengan teliti ciri ciri bahan mentah yang mereka pakai untuk membuat alat-alat tersebut. Tiap kebudayaan selalu mempunyai suatu himpunan pengetahuan tentang alam, tumbuh-tumbuhan, binatang, benda, dan manusia yang ada di sekitarnya.

3. Organisasi Sosial

Organisasi Sosial adalah sekelompok masyarakat yang anggotanya merasa satu dengan sesamanya. Sistem kemasyarakatan atau organisasi sosial yang meliputi: kekerabatan, asosiasi dan perkumpulan, sistem kenegaraan, sistem kesatuan hidup, perkumpulan. Unsur budaya berupa sistem sosial merupakan usaha antropologi untuk memahami bagaimana manusia membentuk masyarakat melalui berbagai kelompok sosial. Tiap kelompok masyarakat kehidupannya diatur oleh adat istiadat dan aturan-aturan mengenai berbagai macam kesatuan di dalam lingkungan di mana dia hidup dan bergaul dari hari ke hari.

4. Sistem Peralatan Hidup dan Teknologi

Manusia selalu berusaha untuk mempertahankan hidupnya sehingga mereka akan selalu membuat peralatan atau benda-benda. Perhatian awal para antropolog dalam memahami kebudayaan manusia berdasarkan unsur teknologi yang dipakai suatu masyarakat berupa benda-benda yang dijadikan sebagai peralatan hidup dengan bentuk dan teknologi yang masih sederhana. Dengan demikian, bahasan tentang unsur kebudayaan yang termasuk dalam peralatan hidup dan teknologi merupakan bahasan kebudayaan fisik.

5. Sistem Mata Pencaharian Hidup

Mata pencaharian atau aktivitas ekonomi suatu masyarakat menjadi fokus kajian penting etnografi. Penelitian etnografi mengenai sistem mata pencaharian mengkaji bagaimana cara mata pencaharian suatu kelompok masyarakat atau sistem perekonomian mereka untuk mencukupi kebutuhan hidupnya. 


\section{Sistem Religi}

Asal mula permasalahan fungsi religi dalam masyarakat adalah adanya pertanyaan mengapa manusia percaya kepada adanya suatu kekuatan gaib atau supranatural yang dianggap lebih tinggi daripada manusia dan mengapa manusia itu melakukan berbagai cara untuk berkomunikasi dan mencari hubungan-hubungan dengan kekuatankekuatan supranatural tersebut.

7. Kesenian

Perhatian ahli antropologi mengenai seni bermula dari penelitian etnografi mengenai aktivitas kesenian suatu masyarakat tradisional. Deskripsi yang dikumpulkan dalam penelitian tersebut berisi mengenai benda-benda atau artefak yang memuat unsur seni, seperti patung, ukiran, dan hiasan. Penulisan etnografi awal tentang unsur seni pada kebudayaan manusia lebih mengarah pada teknik - teknik dan proses pembuatan benda seni tersebut. Selain itu, deskripsi etnografi awal tersebut juga meneliti perkembangan seni musik, seni tari, dan seni drama dalam suatu masyarakat. ${ }^{19}$

Sementara Selo Soemardjan dan Soeleman Soemardi merumuskan kebudayaan sebagai semua hasil karya, rasa dan cipta masyarakat. Karya masyarakat menghasilkan teknologi dan kebudayaan kebendaan atau kebudayaan jasmaniah yang diperlukan oleh manusia untuk menguasai alam sekitarnya agar kekuatan serta hasilnya dapat diabadikan untuk keperluan masyarakat. ${ }^{20}$

Kebudayaan dapat diartikan juga sebagai seperangkat nilai, gagasan vital, dan keyakinan yang menguasai dan menjadi pedoman bagi terwujudnya pola-pola tingkah laku anggota masyarakat yang bersangkutan. Oleh karena itu kebudayaan mencakup segala cara berfikir, merasakan dan bertindak. Seperti yang dikemukakan oleh Peursen yang menyatakan bahwa kebudayaan meliputi segala perbuatan manusia,

${ }^{19} \mathrm{Ibid}, 8$.

${ }^{20}$ Jacobus Ranjabar, Sistem Sosial Budaya Indonesia; Suatu Pengantar (Bogor: Ghalia Indonesia, 2006) 21. 
misalnya cara manusia menghayati kematian dan membuat upacaraupacara untuk menyambut peristiwa penting, demikian juga mengenai kelahiran. ${ }^{21}$

Geertz dalam bukunya "Mojokuto; Dinamika Sosial Sebuah Kota di Jawa”, mengatakan bahwa budaya adalah suatu sistem makna dan simbol yang disusun dalam pengertian dimana individu- individu mendefinisikan dunianya, menyatakan perasaannya dan memberikan penilaianpenilaiannya, suatu pola makna yang ditransmisikan secara historis, diwujudkan dalam bentuk- bentuk simbolik melalui sarana dimana orangorang mengkomunikasikan, mengabdikan, dan mengembangkan pengetahuan, karena kebudayaan merupakan suatu sistem simbolik maka haruslah dibaca, diterjemahkan dan diinterpretasikan ${ }^{22}$.

Ralph Linton memberikan definisi kebudayaan yang berbeda dengan kebudayaan dalam kehidupan sehari- hari kebudayaan adalah seluruh cara kehidupan dari masyarakat dan tidak hanya mengenai sebagian tata cara hidup saja yang dianggap lebih tinggi dan lebih diinginkan"23

Dari berbagai uraian yang telah menjelaskan tentang pengertian sedekah bumi dan unsur- unsur yang ada dalam budaya, maka dapat dipahami bersama bahwa sedekah bumi yang dilakukan masyarakat Pancur merupakan bagian dari budaya karena hal tersebut merupakan bagian dari hasil cipta dan karya manusia yang dilakukan secara turun temurun, selain itu juga didalamnya mengandung berbagai unsur yang ada dalam kebudayaan, diantaranya kepercayaan atau religi serta unsur kesenian.

\section{Budaya Masyarakat Pancur}

Warga desa Pancur merupakan warga yang selalu menjaga tradisi secara turun temurun, berbagai tradisi atau budaya yang dilakukan oleh masyarakat desa Pancur dalam memperingati berbagai hal yang terjadi di

\footnotetext{
${ }^{21}$ Van Puersen, Strategi Kebudayaan (Yogyakarta: Kanisius, 1988), 11.

${ }^{22}$ Kuper, Adam, Culture (Cambridge: Harvard University Press, 1999), 98.

${ }^{23}$ Leonard Siregar, "Antropologi dan Konsep Kebudayaan", Jurnal Antropologi Papua,

Vol. 1, No. 1 (Agustus, 2002), 4-6.
} 
lingkungan mereka, seperti melakukan tradisi tujuh lingkaran hidup yakni mithoni atau tingkeban, brokohan, tedhak sithen, aqiqohan, lamaran, nikahan dan kematian. Upacara pokok lingkaran hidup menjadi rutin dilakukan oleh maysarakat desa Pancur.

Tradisi mlakukan upacara lingkaran hidup dilakukakan ketika sudah tiba waktu untuk melakukannya, seperti mithoni atau tingkeban yang dilakukan ketika usia kandungan seorang ibu sudah berumur 7 bulan, kemudian brokohan dilakukan ketika bayi sudah lahir, tedhak sithen yakni tradisi menginjak tanah untuk bayi yang baru pertama bisa jalan atau sekitar umur 8 bulan, aqiqohan dilakukan oleh masyarakat ketika bayi sudah menginjak dewasa atau menjadi anak - anak. Ketika menginjak dewasa maka akan dilakukan tradisi lamaran sebelum menikah, kemudian melakukan tradisi nikahan dan yang terakhir upacara kematian. Berikut ini dijelaskan tradisi lingkaran hidup yang dilakukan oleh masyarakat Pancur:

1. Tradisi mithoni atau tingkeban dilakukan oleh masyarakat ketika usia kehamilan sudah menginjak 7 bulan, makanya diistilahkan dengan istialh mithoni dari bahasa jawa yang artinya angka tujuh. Tradisi mithoni di desa Pancur dilakukan ketika usia kandungan menginjak usia 7 bulan. Tradisi ini dimulai dengan mengundang seluruh warga sekitar rumah kurang lebih 40 an undangan untuk hadir di acara shohidul bait (yang sedang punya hajat mithoni). Ketika semua undangan telah hadir, maka prosesi acara dimulai dengan do'a bersama yang dipimpin oleh seorang modin, do'a bertujuan untuk memohon kebaikan dan kelancaran serta kebaikan buat calon bayi. Setelah do'a selesai kemudian dilakukan upacara siraman, yang dilakukan di depan rumah. Calon ibu disiram menggunakan air yang didalamnya sudah diberi berbagai macam bunga, dicampur jadi satu di dalam baskom besar. Calon ibu duduk di kursi dan mulai disiram, yang pertama melakukan siraman adalah calon nenek, kemudian calon kakek dan dilanjutkan oleh calon bapak dari bayi. Siraman ini bertujuan untuk mensucikan ibu dan calon bayi yang sedang dikandung baik lahir maupun batin. Setelah acara siraman selesai 
calon ibu kemudian diajak masuk kedalam rumah untuk berganti pakaian kembali. Acara kemudian dilanjutkan dengan pembagian berkat atau makanan yang sudah disiapkan oleh shohibul bait untuk dibawah pulang oleh para undangan.

2. Acara brokohan adalah tradisi untuk menyambut kelahiran bayi, dilaksanakan ketika seorang bayi dilahirkan di dunia. Tradisi brokohan dilakukan dengan tujuan untuk memohon barokah serta keselamatan terhadap bayi. Hal ini bisa dilihat dari arti brokohan dalam bahasa jawa yang diambil dari bahasa arab "barokah" yang berarti berkah. Tradisi brokohan di desa Pancur dilaksanakan dengan mengundang warga sekitar rumah untuk hadir dalam menyambut lahiran bayi. Tradisi dimulai dengan megubur ari - ari yang biasanya dilakukan oleh keluarga shohibul bait, kemudian warga yang hadir diajak berdo'a bersama untuk mendoakan bayi agar mendapat keselamatan, keberkahan dalam menjalankan hidup. Setelah do'a selesai para undangan diberi berkat yang berisi nasi dan lauk pauknya untuk dibawa pulang.

3. Tedhak siten merupakan tradisi turun tanah untuk bayi yang berusia 8 sampai 11 bulan, yakni ketika bayi mulai bisa berjalan di atas tanah. Tradisi ini masih kental dilakukan oleh masyarakat jawa pada umumnya, di desa Pancur tradisi ini juga dilakukan ketika bayi mulai bisa berjalan di atas tanah. Prosesi tedak siten dimulai di pagi hari dengan serangkaian makanan tradisional untuk selamatan. Makanan tradisional tersebut berupa 'jadah'/'tetel' tujuh warna. Makanan ini terbuat dari beras ketan yang dicampur dengan parutan kelapa muda dan ditumbuk hingga bercampur menjadi satu dan bisa diiris. Beras ketan tersebut diberi pewarna merah, putih, hitam, kuning, biru, jingga dan ungu. Jadah ini menjadi simbol kehidupan bagi si kecil, sedangkan warna-warni yang diaplikasikan menggambarkan jalan hidup yang harus dilalui si bayi kelak. Penyusunan jadah ini dimulai dari warna hitam hingga ke putih, sebagai simbol bahwa masalah yang berat nantinya ada jalan keluar / titik terang. Makanan tradisional lainnya yang disediakan untuk acara tedak siten ini berupa 
tumpeng dan perlengkapannya serta ayam utuh. Tumpeng sebagai simbol permohanan orang tua agar si bayi kelak menjadi anak yang berguna, sayur kacang panjang sebagai simbol umur panjang, sayur kangkung sebagai simbol kesejahteraan, kecambah sebagai simbol kesuburan, sedangkan ayam adalah simbol kemandirian. Setelah acara selamatan dengan mengumpulkan para undangan dan telah dibagikan tumpengan serta berkatnya, rangkaian acara tedak siten dilanjutkan dengan prosesi menapakkan kaki si kecil diatas jadah 7 warna, kemudian bayi disuruh memilih berbagai jenis mainan yang melambangkan profesi pekerjaan dan al qur'an. Pilihan bayi tersebut pertanda sebagai harapan bahwa kelak bayi nanti akan menjadi seperti symbol mainan yang sudah dipilihnya. Seperti ketika bayi memilih al-Qur'an maka diharapkan nanti bayi akan menjadi anak yang soleh atau ustadz, memilih mainan pistol maka nanti bayi diharapkan akan menjadi seorang polisi, dan seterusnya. Setelah prosesi pemilihan mainan, maka sang ibu akan menebarkan beras kuning (beras yang dicampur dengan parutan kunir) yang telah dicampur dengan uang logam untuk diperebutkan oleh undangan anak-anak, dimaksudkan agar si kecil memiliki sifat dermawan. Rangkaian prosesi tedak siten diakhiri dengan memandikan si kecil ke dalam air bunga setaman lalu dipakaikan baju baru. Prosesi pemakaian baju baru inipun dengan menyediakan 7 baju, yang pada akhirnya baju ke-7 yang akan dia pakai. Hal ini menyimbolkan pengharapan agar si kecil selalu sehat, membawa nama harum bagi keluarga, hidup layak, makmur dan berguna bagi lingkungannya.

4. Aqiqohan, merupakan tradisi yang sudah umum dilingkungan umat Islam, tradisi ini dilaksanakan warga desa Pancur ketika seorang bayi sudah menginjak dewasa, akan tetapi beberapa juga melakukan aqiqohan ketika anak masih kecil disertai dengan memberi nama anak. Aqiqoh dilaksanakan dengan melakukan penyembelihan hewan ternak berupa kambing, untuk anak laki - laki maka disembelih 2 ekor kambing, dan anak perempuan menyembelih 1 ekor kambing. Setelah kambing dipotong dan diolah menjadi 
masakan, warga sekitar rumah diundang hadir untuk memberikan do'a kepada bayi sekaligus memberi informasi kepada warga sekitar rumah nama yang diberikan untuk bayi. Acara dilakukan dengan membaca sholawat Nabi, kemudian bayi digendong oleh bapaknya untuk diajak berputar mengelilingi undangan yang sedang membaca sholawat mahallul qiyam. Setelah selesai mahallul qiyam kemudian dilakukan do'a dan pembagian berkat. Tradisi aqiqoh ini dilakukan sebagai bentuk penebusan terhadap bayi yang sudah dilahirkan.

5. Lamaran, Hal menarik yang dapat diketahui dari desa ini adalah adat pernikahan yang unik. Di desa ini yang meminang duluan adalah pihak perempuan bukan pihak laki-laki. Di sini yang dimuliakan adalah pihak laki-laki. Hal ini terjadi jika pasangan yang melakukan lamaran sama - sama berasal dari desa Pancur, tapi jika yang laki laki berasal dari luar desa atau berasal dari daerah lain maka yang laki- laki terlebih dahulu melamar kepada yang perempuan. Dalam tradisi lamaran ketika perempuan desa Pancur dilamar oleh laki laki dari daerah lain, maka yang dilakukan adalah dengan membawa berbagai jenis jajan, yakni tetel, wingko, roti, dan berbagai jenis buah - buahan, serta yang tidak lupa juga membawa penyingset yakni peralatan keseharian perempuan, seperti bedak, alat kecantikan yang lain dan berbagai kelengkapan yang dipakai perempuan, berbagai perlengkapan seserahan lamaran tersebut kemudian dibawa kerumah mempelai perempuan. Dalam proses melamar tidak hanya memprioritaskan membawa jajan, namun juga menbicarakan bahwa tujuan kedatangan ke rumah adalah untuk meminta restu terhadap orang tuanya. Selang beberapa hari kemudian, gentian dari mempelai perempuan yang berkunjung ke rumah mempelai laki - laki dengan membawa berbagai jenis jajanan sebagai bentuk balasan.

6. Pernikahan, sebelum melakukan resepsi pernikahan, terlebih dahulu sepasang pasangan laki dan perempuan melakukan akad nikah di kantor urusan agama kecamatan Temayang. Setelah melakukan akad nikah kemudian dilanjutkan dengan resepsi pernikahan yang digelar dirumah mempelai perempuan. Acara pernikahan dimulai dengan 
mengundang family dan teman mempelai perempuan untuk hadir dalam acara tersebut. Pasangan mempelai duduk bersama di atas kursi pelaminan, disaksikan oleh semua undangan. Dalam acara resepsi juga dilakukan beberapa sambutan, seperti sambuatn seserahan pengantin laki -laki, sambutan penerimaan pengantin perempuan, kemudian ditutup dengan ceramah atau tausiyah oleh ulama' sebagai bekal mempelai, untuk mengarungi bahterah rumah tangga sekaligus do'a penutup. Setalah rangkaian acara dilakukan kemudian para undangan diberi makan bersama sembari diiringi musik, dan setelah selesai makan satu persatu undangan meninggalkan acara.

7. Kematian, upacara kematian dilakukan ketika salah seorang warga desa Pancur meninggal dunia. Tradisi yang dilakukan seperti hal nya tradisi di daerah lain ketika ada warga yang meninggal, yakni melakukan rawat jenazah dengan memandikan jenazah, mengkafani, mensholati, dan mengkubur jenazah.

Selain tradisi upacara lingkaran hidup, di desa Pancur juga dikenal beberapa tradisi yang rutin dilakukan setiap tahunnya dan sudah secara turun - temurun dilakukan, diantranya adalah megengan, ketupatan dan tradisi sedekah bumi. Tradisi megengan dilakukan dengan mengundang warga sekitar rumah untuk berdo'a, kemudian membagikan jajan atau berkat kepada tetangga sekitar menjelang bulan ramadlan, di dalam berkat tersebut berisi makanan nasi dan kue apem. Pemberian kue apem sebagai simbol untuk meminta maaf kepada para tetangga menjelang datangnya bulan ramadlan. ${ }^{24}$

\section{Sejarah Sedekah Bumi di Pancur}

Sedekah bumi merupakan tradisi masyaratkat Jawa yang telah dilakukan secara turun temurun. Sebagai salah satu ritual khas masyarakat Jawa, tradisi sedekah bumi dilakukan setiap tahunnya oleh masyarakat Jawa sebagai bentuk ucapan syukur atas nikmat yang diberikan dari hasil bercocok tanam. Sedangkan ritual mengingatkan manusia tentang

24Pertiwi, Wawancara, Bojonegoro, 02 April 2015. 
eksistensi dan hubungannya dengan lingkungan. Melalui ritual warga masyarakat dibiasakan untuk menggunakan simbol dari berbagai acara sosial dalam kehidupan sehari-hari. Ritual juga merupakan pengetahuan tentang bagaimana seseorang bertindak dan bersikap terhadap gejala yang diperolehnya lewat proses belajar dari generasi sebelumnya dan kemudian diwariskan kepada generasi berikutnya ${ }^{25}$.

Selain itu, ritual keagamaan merupakan unsur kebudayaan yang universal, sulit diubah dan sulit dipengaruhi oleh kebudayaan lain, ritual lebih menunjukkan perilaku tertentu yang bersifat formal yang dilakukan secara berskala, bukan sekedar rutinitas yang bersifat teknis namun didasari keyakinan religius terhadap kekuasaan atau kekuatan mistis ${ }^{26}$. Dalam ritual terdapat simbol-simbol berupa sesaji, tumbal dan ubarambe yang menghubungkan dengan warga masyarakat karena dalam kehidupan sehari-hari tanpa disadari menggunakan simbol, seperti simbol dari bahasa dan gerak-gerik. Karena simbol berkaitan erat dengan kohesi sosial dan transformasi sosial ${ }^{27}$.

Catherine Bell mendefinisikan ritual sebagai ide untuk mengekspresikan keyakinan/agama secara simbolik dengan tujuan berkelanjutan/continue ${ }^{28}$. Dhavamony mengutip Susanne Langer bahwa ritual sebagai ungkapan yang bersifat logis daripada bersifat psikologis, yaitu pengobyekan simbol-simbol. Simbol-simbol ini mengungkapkan perilaku dan perasaan, serta membentuk disposisi pribadi para pemuja yang mengikuti modelnya masing-masing. Pengobyekan ini penting untuk kelanjutan dan kebersamaan dalam kelompok dalam melaksanakan pemujaan $^{29}$.

\footnotetext{
${ }^{25}$ Gilbert Lewis, Day of Shining Red; An Essay Understanding Ritual (New York: Cambridge University Press, 1980), 50.

${ }^{26}$ Victor Turner, Simbol in Ndembu Ritual, in Victor Turner, The Forest of Simbol: Aspect of Ndembu Ritual (Ithica: Cornell University Press, 1967), 19.

${ }^{27}$ Dillistone, Daya Kekuatan Simbol (Yogyakarta: Kanisius, 2002), 2.

${ }^{28}$ Catherine Bell, Ritual Theory; Ritual Practice (New York: Oxford University Press, 2003), 15 ,

${ }^{29}$ Marisusai Dhavamony, Fenomenologi Agama (Yogyakarta: Kanisius, 1995), 174.
} 
Simbol-simbol yang disajikan dan diperlihatkan dalam ritual dikaitkan dengan mitos tentang dunia, meringkas kualitas kehidupan emosional dengan bertindak atau aktif dalam penyelenggaraannya. Simbol-simbol sacral menghubungkan ontologi, kosmologi dengan estetika dan moralitas. Kekuatan khas simbol-simbol itu berasal dari kemampuan warga masyarakat untuk mengidentifikasikan fakta dengan nilai fundamental untuk sesuatu yang bersifat faktual murni pada muatan normatif yang komprehensif. Simbol-simbol sakral yang terjalin menjadi sebuah keseluruhan yang teratur itu membentuk sebuah sistem religius ${ }^{30}$. Ritual yang sering kita temui dimasyarakat Jawa seperti sedekah bumi kental akan keberadaan simbol yang digunakan dalam pelaksanaanya, seperti tumpeng dan sesajen. Selain itu, ritual dalam tradisi masyarakat Jawa dilakukan untuk berdo'a dan mendapatkan suatu keberkahan, Juga berfungsi untuk menghormati para leluhur yang sudah meninggal.

Tradisi sedekah bumi merupakan salah satu bentuk ritual yang dilakukan oleh masyarakat yang berprofesi sebagai petani, yang menggantunggkan hidupnya dari mengais rizqi dan memanfaatkan kekayaan alam yang ada di bumi. Bagi masyarakat jawa khususnya para petani, tradisi ritual tahunan semacam sedekah bumi bukan hanya sebagai rutinitas belaka, akan tetapi mempunyai makna yang lebih dari itu, yakni sebagai bentuk penghormatan kepada Tuhan yang memberikan rizqi lewat pertanian.

Secara umum, Menurut cerita dari nenek moyang orang jawa, tanah merupakan pahlawan yang cukup besar bagi kehidupan manusia di muka bumi. Maka dari itu tanah harus diberi penghargaan yang layak dan besar. Sedekah bumi, menurut mereka adalah salah satu simbol paling dominan untuk menunjukkan rasa cinta sebagai manusia atas bumi yang telah memberi kehidupan bagi manusia. Dengan begitu maka tanah yang dipijak tidak akan pernah marah, seperti longsor dan banjir.

Selain itu, Sedekah bumi juga merupakan salah satu bentuk syukur kepada Tuhan atas nikmat dan berkah yang telah diberikan-Nya. Sedekah

${ }^{30}$ Geertz, Abangan, Santri, Priyai dalam Masyarakat Jawa (Jakarta: Pustaka Jaya, 1983), 51. 
bumi pada umumnya dilakukan sesaat setelah masyarakat habis menuai panen raya. Permulaan sedekah bumi di desa Pancur tidak ada yang tahu sejak kapan dimulainya, karena mereka hanya menerima dari nenek moyang secara turun menurun. Masyarakat hanya tahu dari tradisi nenek moyangnya saja, tidak tahu asal muasal pelaksanaannya dulu bagaimana. ${ }^{31}$

Namun dari beberapa penjelasan, mengungkapkan bahwa masyarakat Pancur masa dulu, selalu mendapatkan hasil panen yang melimpah, karena sawah yang mereka tanami mendapatkan aliran air dari sendang desa. Akan tetapi seiring dengan berjalannya waktu sendang desa tersebut berhenti tidak lagi mengeluarkan air. Hal ini, kemudian memberikan inisiatif kepada warga desa untuk melakukan penghormatan serta pemberian ucapan terimakasih kepada roh- roh penjaga sendang yang telah memberikan aliran air untuk sawah- sawah mereka ${ }^{32}$, tradisi ini kemudian berlangsung setiap tahun setelah masyarakat selesai melakukan panen raya.

Sedekah bumi dimulai dengan melakukan pembakaran sesaji di sendang desa, sinkretisme jawa ke hindu an terasa kental dalam pelaksanaannya. Hal ini berlangusng secara turun - temurun dari nenek moyang masyarakat desa. Namun pada tahun 1980an nilai- nilai keislaman masyarakat desa Pancur semakin menguat. Intensitas penguatan nilai- nilai keislaman tersebut tampak dalam kehidupan masyarakat, baik secara pribadi maupun secara umum, misalnya dengan semakin besarnya perhatian masyarakat untuk membangun tempat ibadah, Masjid, serta musholla, serta semakin banyaknya masyarakat yang malakukan aktifitas peribadatan di masjid. Selain itu juga tampak pada adanya lembaga - lembaga pendidikan yang berbasis Islam, serta organisasi- organisasi yang berorientasi pada pengembanganan dan penguatan nilai keislaman. Penguatan nilai- nilai keislaman tersebut berdampak pada tata niat dan tata nilai prosesi pelaksanaan budaya sedekah bumi. Tujuan tujuan awal mempersembahkan syukuran untuk

\footnotetext{
${ }^{31}$ Suto, Wawancara, Bojonegoro, 02April 2015.

32Sarkam, Wawancara, Bojonegoro, 01April 2015.
} 
para roh yang ada di sendang berubah menjadi niatan mengucapkan syukur ata pemberian Tuhan dari hasil bumi, sekalipun pelaksanaannya tetap dilaksanakan di sendang, untuk menghormati tradisi, meskipun ada juga beberapa masyarakat yang masih percaya terhadap keberadaan roh di sendang yang perlu untuk dikirimi do'a dan sesajen.

Masyarakat yakin adanya Allah, yakin bahwa Muhammad adalah utusan Allah, yakin adanya Nabi-Nabi lain, yakin adanya tokoh-tokoh Islam yang keramat, namun mereka juga yakin adanya roh- roh tertentu yang menguasai bagian-bagian dari alam semesta, yakin adanya makhlukmakhluk halus penjelmaan nenek moyang atau orang yang sudah meninggal, yakin adanya roh-roh penjaga tempat tertentu. ${ }^{33}$ Oleh karena itu masyarakat tetap melaksanakan prosesi sedekah bumi yang sudah menjadi tradisi turun temurun, selain sebagai bentuk penghormatan dan penghargaan terhadap para sesepuh desa, pelaksanaan sedekah bumi yang digelar di sendang juga sebagai bentuk usaha untuk melestarikan keberadaan sendang yang menjadi awal sejarah adanya cerita desa Pancur.

\section{Nilai- Nilai Dalam Pelaksanaan Tradisi Sedekah Bumi}

Setiap prosesi budaya yang dilakukan oleh sekelompok masyarakat tidak lepas dari maksud serta tujuan yang terkandung didalamnya. Dalam melaksanakan budaya sedekah bumi masyarakat desa Pancur juga tidak lepas dari makna yang menjiwai dilaksanakannya prosesi budaya tersebut. Dalam beberapa wawancara yang sudah peneliti lakukan secara umum masyarakat mengatakan bahwa budaya sedekah bumi tetap dilakukan dengan tujuan untuk mengucapkan rasa syukur atas limpahan rizki dari hasil panen yang diberikan oleh Tuhan yang maha esa. Selain dari pada itu melestarikan budaya nenek moyang juga menjadi bukti bahwa generasi penerus tetap menghormati dan melestarikan warisan budaya. ${ }^{34}$

\footnotetext{
33Suto, Wawancara, Bojonegoro, 02 April 2015.

${ }^{34}$ Tulus, Wawancara, Bojonegoro, 02 April 2015.
} 
Sedangkan secara umum nilai yang terkandung dari pelaksanaan sedekah bumi di Desa Pancur Kecamatan Temayang Kabupaten Bojonegoro adalah meliputi sebagaimana berikut:

a. Nilai sosiologis, dimensi terpenting dari ritual sedekah bumi ini adalah memberikan makna sosial-religius kepada umat atau masyarakat yang melangsungkan ritualtersebut.Aspekreligiusitas dari pelaksanaan ritual sedekah bumi, hendaknya dapat diserap oleh masyarakat sehingga dapat berdaya guna untuk menimbulkan perubahan sosial ke arah yang makin baik yaitu terciptanya suatu kebersamaan dan kekompakan. Kekompakan dari masyarakat dalam pelaksanaan sedekah bumi pada masyarakat di desa Pancur, dapat memberikan makna tersendiri dalam menciptakan atmosfir kebersamaan dalam meningkatkan keeratan sosial di tengah kehidupan masyarakat yang semakin individualis dalam kehidupan masyakarat global. Secara sosial, ritual tersebut dapat semakin meningkatkan dinamika umat dalam keakraban sosial yang produktif, keakraban sosial yang dinamis dapat menciptakan kondisi sosial yang kondusif untuk mengembangkan pemikiran-pemikiran, wacana dan perilaku sosial yang dapat menciptakan intregasi sosial yang makin meningkat baik dalam lingkungan masyarakat kecil, seperti keluarga, maupun lingkungan masyarakat yang lebih luas. Makna tradisi sedekah bumi dapat diberikan reintepretasi sebagai media mewujudkan solidaritas sosial. Pada tingkat interaksi sosial pada proses-proses sosial yang merupakan hubungan-hubungan sosial dinamis, menyangkut hubungan antara orang perorangan, atau kelompok-kelompok yang melibatkan berbagai clan, maupun antara individu dengan kelompok masyarakat tersebut.

b. Nilai teologis, Sikap pasrah kepada penguasa alam dan hormat kepada leluhur merupakan salah satu karakter masyarakat pedesaan yang mayoritas hidup sebagai petani, sikap itu bahkan sudah melekat dan menjadi budaya masyarakat jawa pada umumnya.

c. Nilai ekologis, Selanjutnya nilai yang terdapat dari pelaksanaan sedekah bumi ini adalah nilai cinta pada alam sekitar sebagai bukti 
rasa cinta masyarakat pada Tuhannya, masyarakat Desa Pancur Kecamatan Temayang Kabupaten Bojonegoro tetap melestarikan dan menjaga keberadaan sendang yang menjadi tempat dilaksanakannya prosesi ritual sedekah bumi, sehingga demi menjaga agar sumber air yang ada pada sendang tersebut tetap ada, masyarakat Desa Pancur Kecamatan Temayang Kabupaten Bojonegoro tetap membiarkan kondisi sekitar sendang tumbuh dengan pepohonan yang rindang karena dengan banyaknya pohon di daerah sekitar sendang maka sumber air yang ada disendang tersebut akan tetap ada.

\section{Respon Masyarakat Terhadap Tradisi Sedekah Bumi}

Saat masyarakat desa Pancur antusias melaksanakan tradisi sedekah bumi, ada juga diantara masyarakat yang tidak ikut serta melaksanakan tradisi tersebut, perbedaan pandangan terhadap arti serta kegiatan sedekah bumi membuat beberapa orang tidak ikut serta dalam kegiatan tersebut, meskipun beberapa orang juga ikut serta dalam kegiatan tersebut. Perbedaan respon dalam pelaksanaan tradisi sedekah bumi tidak sampai pada hal yang sifatnya memecah belah persatuan dan kesatuan masyarakat desa Pancur. Masyarakat desa Pancur menghormati terhadap adanya perbedaan respon dalam memahami tradisi sedekah bumi.

a. Respon Masyarakat Yang Tidak Ikut Sedekah Bumi

Tradisi seperti sedekah bumi, sedekah laut atau berbagai tradisi lain yang ada dimasyarakat, yang merupakan hasil akulturasi berbagai budaya selalu menimbulkan pro kontra di tengah - tengah masyarakat. Beberapa masyarakat Muslim menganggap hal tersebut sebagai sebuah prilaku yang musyrik karena tidak sesuai dengan apa yang diajarkan agama Islam.

Sementara Mark. R Woodward dalam analisanya tentang Islam di Jawa, yang membahas tentang persoalan syirik pada unsur-unsur Hindu dalam Islam Jawa. Dia lebih memberikan perhatiannya pada penafsiran doktrin, praktik, dan mitos Hindu-Jawa di dalam Islam Jawa. Syirik menjadi perdebatan yang hebat antara batasan santri tradisional dan penafsiran kejawen. Posisi santri mengalami suatu 
transformasi yang akan membawanya segaris dengan teori-teori ulama yang berorientasi pada Syari'at. Akan tetapi ada juga suatu komunitas santri tradisional yang signifikan yang penafsirannya tidak berbeda jauh dengan kalangan Muslim kejawen. ${ }^{35}$

Elit keagamaan masyarakat desa Pancur yang menjadi informan bagi peneliti mengatakan bahwa dia tidak ikut serta dalam pelaksanaan tradisi sedekah bumi dikarenakan adanya kekhawatiran salah persepsi bagi orang lain. Hal ini tidak lepas dari perdebatan soal syirik atau bukan. Oleh karenanya sebagai seorang elit keagamaan, informan tersebut berusaha untuk tidak terjebak pada pandangan syirik atau bukan. Akan tetapi sebenarnya yang terpenting menurutnya adalah niat melakukan hal tersebut, dan niat itu ada di dalam hati sehingga tidak ada yang tahu. ${ }^{36}$ Oleh karenanya meskipun beberapa masyarakat tidak ikut dalam acara tersebut akan tetapi mereka juga tidak pernah secara frontal melarang pelaksanaan tradisi tersebut.

b. Respon Masyarakat Yang Ikut Sedekah Bumi

Tradisi sedekah bumi di desa Pancur juga banyak diikuti oleh warga desa, beberapa memiliki keyakinan dan respon tersendiri dalam memaknai kegiatan tersebut, diantaranya adalah generasi muda yang tergabung dalam komunitas BOPAC (Bocah Pancur), aparat desa dan sesepuh desa.

1. Pandangan Generasi Muda Desa

Generasi muda merupakan generasi penerus dalam lingkup kehidupan bermasyarakat. Tongkat estafet dalam segala hal yang ada dalam suatu komunitas akan diteruskan oleh mereka yang masih muda. Generasi muda Pancur yang tergabung dalam komunitas BOPAC menjadi penerus sekaligus penjaga keberlangsungan tradisi sedekah bumi yang ada dise desa Pancur. Keberadaan pemuda Pancur tersebut dalam pelaksanaan

\footnotetext{
${ }^{35}$ Woodward, Islam Jawa; Kesakralan Normatif versus Kebatinan (Yogyakarta: LKiS, 1999).

${ }^{36}$ K. Roqib, Wawancara, Bojonegoro, 07 November 2015.
} 
tradisi sedekah bumi merupakan suatu hal yang bersifat positif dalam rangka menjaga dan melestarikan kebudayaan sedekah bumi.

Generasi muda Pancur yang ikut serta dalam kegiatan tersebut tidak mempunyai niatan yang khusus. Bagi mereka momentum kebersamaan dan gotong royong antar pemuda. Karena dengan adanya momentum sedekah bumi tersebut para pemuda desa Pancur mampu bekerjasama dalam pelaksanaan tradisi tersebut. ${ }^{37}$

Di desa Pancur kelompok pemuda terbagi dalam beberapa kelompok diantaranya ada ikatan pencak silat setia hati teratai, ada juga pencak silat kera sakti dan kelompok pernafasan margaluyu. Akan tetapi berbagai perbedaan kelompok tersebut melebur menjadi satu kebersamaan dalam pelaksanaan tradisi sedekah bumi.

2. Pandangan Sesepuh Desa

Sebagian sesepuh desa Pancur mempercayai hal gaib dan keramat yang sulit dinalar secara rasional, misalnya tentang Danyang yang dianggap sebagai penunggu sendang dan memberikan kesejahteraan melalui air untuk sawah masyarakat, sehingga menurut mereka harus dihormati.

Beberapa sesepuh desa menganggap sedekah bumi sebagai ritual religi yang bersifat wajib, timbul rasa bersalah apabila tidak berpartisipasi. Bagi mereka ritual sedekah bumi harus dilaksanakan apabila tidak ingin sesuatu yang buruk menimpa desa; dan tiap individu menghindari melakukan pantangan agar tidak membuat danyang marah, atau merupakan sesuatu yang wajib dilakukan. Seperti yang diungkapkan oleh Mbah Jo yang menceritakan betapa masyarakat zaman dahulu melalukannya dengan meriah dan sangat antusias. ${ }^{38}$

${ }^{37}$ Hendra, Wawancara, Bojonegoro, 02 April 2015.

${ }^{38} \mathrm{Mbah}$ Jo, Wawancara, Bojonegoro, 02 April 2015. 
Gambaran di atas memperlihatkan bahwa beberapa sesepuh masyarakat desa Pancur yang ikut serta dalam tradisi sedekah bumi memiliki pandangan yang bercorak iman atau percaya terhadap danyang, sehingga mereka merasa berkewajiban melaksanakan sedekah bumi tiap tahun dalam ritual tercakup sesaji, mitos, dan hiburan yang dilaksanakan bersama-sama menunjukkan warga masyarakat Jawa di Desa Pancur menyakini bahwa ritual sedekah bumi memiliki makna dan fungsi bagi keselamatan hidup.

Penyelenggaraan sedekah bumi secara rutin itu dilatarbelakangi pula oleh adanya kekhawatiran akan gangguan fisik dan non fisik yang tiap saat dapat menimpa mereka jika ritual itu tidak dilaksanakan. jadi, sedekah bumi dapat digolongkan kepada jenis tradisi krisis yang sekaligus tradisi religius, karena dari pelaksanaannya diharapkan berdampak positif bagi keselamatan seluruh warga masyarakat. Hakikatnya, pelaksanaan sedekah bumi adalah ungkapan sikap pasrah diri kepada Tuhan Yang Maha Kuasa, yang mencerminkan keterikatan manusia dengan Tuhannya.

Namun beberapa sesepuh desa juga menyadari bahwa kepercayaan terhadap adanya danyang di sendang desa sudah mulai meluntur, hal ini tentu tidak lepas dari proses penguatan nilai ke Islaman yang terjadi di desa Pancur. Hal ini dibuktikan dengan pembacaan do'a yang menyebutkan nama Allah dalam memohon perlindungan dan mengucapkan rasa syukur yang dibacakan oleh modin Mahfud. ${ }^{39}$

3. Pandangan Aparat Desa

Dalam pelaksanaan tradisi sedekah bumi tahun ini peneliti melihat jajaran perangkat desa turut hadir dalam pelaksanaan tradisi tersebut. Kehadiran dalam tradisi tersebut merupakan bentuk perhatian yang diberikan oleh jajaran aparat desa untuk

${ }^{39}$ Pembacaan Do'a oleh Modin Mahfud pada 2 April 2015 di Bojonegoro. 
melestarikan tradisi budaya masyarakat Pancur. Bahkan bisa dikatakan bahwa tanpa ada dukungan dari jajaran aparat desa maka pelaksanaan tradisi sedekah bumi yang dilaksanakan setiap tahunnya tidak akan dilaksanakan. Sehingga dukungan aparat desa dalam tradisi tersebut menjadi kunci penting.

Kepala desa Pancur menyadari bahwa pelaksanaan tradisi sedekah bumi menimbulkan berbagai tafsiran makna dalam pribadi masyarakat Pancur, akan tetapi kepala desa menjelaskan bahwa pergeseran penafsiran makna dalam tradisi sedekah mulai bergeser kearah yang lebih "santri”. Hal ini dikarenakan semakin intens keberagamaan masyarakat desa Pancur dalam beragama.

Kepala desa menyebutkan bahwa Mayoritas warga masyarakat Pancur adalah Muslim, sebagian mereka menjalankan ritual secara turun temurun dengan mempersembahkan kepada danyang sebagai roh yang membantu mereka, berupa membakar kemenyan (kukus) dan membuat sesaji yang dilakukan secara kolektif dalam bentuk ritual sedekah bumi.

Sesaji merupakan aktualisasi pikiran, keinginan, dan perasaan pelaku sebagai bentuk akumulasi budaya yang bersifat abstrak untuk mendekatkan kepada Tuhan. Sesaji juga sebagai wacana simbol yang digunakan untuk "negosiasi" spiritual dalam kekuatan gaib dengan maksud agar tidak diganggu oleh mahluk halus. Memberi makan secara simbolis kepada roh halus mempunyai tujuan agar roh menjadi jinak dan membantu manusia. Namun sekarang dalam makna sedekah bumi terjadi polarisasi menuju ke-santrin-an dengan acara acara yang kental bernuansa Islam (pembacaan tahlil dan pengajian).

Di masa sebelumnya acara dalam ritual sedekah bumi penuh bernuansa kejawen dan mistik, misalnya berkunjung ke sendang dengan membawa sesaji lengkap pada tengah malam dan pagi hari. Sedangkan acara pengajian tidak dimasukkan dalam acara hiburan melainkan ledekan, jaranan, dan tayub saja. 
Kepala desa menuturkan bahwa masyarakat desa Pancur merupakan masyarakat yang taat kepada agama, akan tetapi mereka juga tidak ingin melupakan tradisi nenek moyang yang sudah terjadi secara temurun dan menjadikan sedekah bumi sebagai bagian dari tardisi yang harus dijaga. ${ }^{40}$

Lain dari pada itu aparat desa juga melihat sedekah bumi dari aspek sosial kemasyarakatannya. Hal ini dikarenakan sedekah bumi manjadi media bagi masyarakat desa Pancur untuk bergotong royong bersama dan menjaga keharmonisan antar individu ataupun kelompok.

\section{Sedekah Bumi sebagai Medan Harmoni}

Dalam praktiknya, pelaksanaan sedekah bumi yang dilaksanakan oleh masyarakat desa Pancur melibatkan seluruh elemen masyarakat, diantaranya adalah unsur pemuda, aparat pemeirntah desa, sesepuh desa, serta masyarakat Pancur pada umunya. Tentu hal ini menjadi momentum yang luar biasa bagi masyarakat Pancur, tatkala semua pihak dapat ikut serta bersatu guyub rukun dalam bingkai budaya sedekah bumi.

Sebagai bagian dari budaya yang mempersatukan seluruh elemen dalam pelaksanaannya, sedekah bumi menjadi medan pemersatu serta memperkuat rasa persatuan dan kesatuan masyarakat desa Pancur, hal ini dapat kita lihat dari antusiasme warga yang hadir dengan penuh semangat kegotongroyongan d an melupakan seluruh dinamika konflik horizontal yang ada di masyarakat. Seperti diketahui bahwa masyarakat Pancur terdiri dari berbagai kelompok, seperti ditingkatan pemuda ada kelompok silat Setia Hati dan Kera Sakti, kedua kelompok ini sering terlibat gesekan yang mengarah konflik. Selain itu ada kelompok Muhammadiyah dan NU, untuk dua kelompok ini belum pernah terjadi konflik horizontal yang mengarah pada kekerasan, akan tetapi secara ideologis masingmasing kelompok memiliki basis penganut yang jelas, tentu basis-basis ini bias menjadi bom waktu yang kapan saja bias memunculkan konflik jika tidak dari dini kita pupuk rasa persatuan, sedekah bumi merupakan salah

${ }^{40}$ Tulus, Wawancara, Bojonegoro, 02 April 2015. 
satu upaya untuk menjadi medan harmoni bagi kehidupan masyarakat desa Pancur.

Berkaitan dengan perbedaan pendapat terhadap pelaksanaan tradisi sedekah bumi, maka hal tersebut menjadi sebuah keberagaman pendapat yang sifatnya tidak dapat saling memaksakan antara yang setuju dan yang tidak setuju, tidak bias dijustifikasi juga bahwa yang tidak setuju melarang keberadaan kegiatan tersebut, ketidaksetujuan dalam perbedaan tanpa memaksakan pendapat yang dipegang merupakan sikap yang ditonjolkan dalam proses pelaksanaan sedekah bumi di Pancur.

\section{Penutup}

Pelaksanaan tradisi sedekah bumi di desa Pancur tidak banyak berbeda dengan pelaksanaan tradisi sedekah bumi pada umunya. Di desa Pancur sendang desa menjadi pusat pelaksanaan tradisi sedekah bumi, hal ini tidak lepas dari kepercayaan masyarakat desa yang mempercayai adanya danyang sebagai penunggu sendang. Sedekah bumi di Pancur dimulai dengan aktifitas membersihkan sendang desa sebagai bentuk pra pelaksanaan tradisi sedekah bumi, setelah itu acara inti dari sedekah bumi yakni pembakaran kemenyan dan membawa beberapa sesaji untuk di bawa menuju sendang sebagai bentuk persembahan terhadap yang kuasa. Pada zaman dahulu, setelah acara inti di sendang desa, rangkaian acara sedekah bumi dilanjutkan dengan pertunjukan seni tayuban saja, akan tetapi seiring dengan semakin menguatnya nilai keagamaan masyarakat desa Pancur, rangkaian pelaksnaan tradisi sedekah bumi diahiri dengan pelaksanaan pengajian umum. Masyarakat desa Pancur memaknai tradisi sedekah bumi sebagai bentuk rasa syukur atas rizqi yang sudah diberikan yang kuasa melalu bumi sebagai tempat bercocok tanam, selain itu juga untuk memohon perlindungan kepada yang kuasa dari berbagai sumber kejadian yang bisa membahayakan keselamatan masyarakat desa Pancur. Berbagai respon muncul dalam tradisi pelaksanaan sedekah bumi yang rutin dilaksanakan setiap tahunnya. Pertama respon negatif, yakni respon bagi mereka yang tidak ikut pelaksanaan sedekah bumi muncul dari elit keagamaan yang menjelaskan tentang persepsi umum dan masih pro kontra dengan istilah syirik. Kedua respon positif, yakni respon dari 
mereka yang ikut serta dalam sedekah bumi muncul dari berbagai keompok, pertama dari golongan muda yang memaknai sedekah bumi sebagai momentum untuk menjaga dan mempererat persatuan dan kesatuan pemuda Pancur, kedua adalah respon dari sesepuh desa yang mengatakan bahwa mereka masih meyakini adanya danyang sebagai penjaga sendang, sehingga menghormati keberadaan danyang dengan melakukan sedekah bumi menjadi suatu rangakian tradisi yang harus dilakukan. Ketiga respon dari aparat desa, sebagai pemegang kekuasaan di desa, aparat desa melihat tradisi sedekah bumi ini sebagai suatu kebudayaan yang patut dijaga karena memiliki dampak sosial bagi masyarakat desa Pancur, yakni mengikat rasa persaudaraan. Terlepas dari perdebatan dan perbedaan pendapat dalam pelaksanaan tradisi sedekah bumi tersebut.

\section{Daftar Pustaka}

Agus, Bustanuddin, Agama dalam kehidupan Manusia, Pengantar Antropologi Agama Jakarta: Raja Grafindo Persada, 2007.

Bell, Catherine, Ritual Theory; Ritual Practice New York: Oxford University Press, 2003.

Dhavamony, Marisusai, Fenomenologi Agama Yogyakarta: Kanisius, 1995.

Damami, Muhamad, Makna Agama dalam Masyarakat Jawa Yogyakarta: LESFI, 2002.

Departemen Pendidikan dan Kebudayaan, Kamus Bahasa Besar Indonesia Jakarta: PT. Balai Pustaka, 2005.

Dillistone, Daya Kekuatan Simbol Yogyakarta: Kanisius, 2002.

Edward, Tylor, B., Primitive Culture; Research into the Development of Mythology, Philosophy, Religion, Language, Art and Custom (1874), dalam Koenjtaraningrat, Sejarah Teori Antropologi I Jakarta: UI Press, 1987. 
Geertz, Clifford, Abangan, Santri, Priyayi dalam Masyarakat Jawa Jakarta: Pustaka Jaya, 1983.

Harsojo, Pengantar Antropologi Jakarta: Abardi, 1984.

Koentjaraningrat, Pengantar Antropologi; Pokok - Pokok Etnografi Jakarta: Rineka Cipta, 1998.

Koentjaraningrat, Pengantar Ilmu Antrpologi Jakarta: Rineka Cipta, 1990.

Koentjaraningrat, Kebudayaan, Mentalitas dan Pembangunan Jakarta: Gramedia Pustaka Utama, 1993.

Kuper, Adam, Culture Cambridge: Harvard University Press, 1999.

Lewis, Gilbert, Day Of Shining Red; An Essay Understanding Ritual New York: Cambridge University Press, 1980.

Manser, Martin H, Oxford Advanced Learns Dictionary New York: Oxford University Press, 2006.

Masimambow, Koentjaraningrat dan Antropologi di Indonesia Jakarta: Yayasan Obor Indonesia, 1997.

Ode, Samsul, "Budaya Lokal Sebagai Media Resolusi dan Pengendalian Konflik di Provinsi Maluku", Jurnal POLITIKA, Vol. 6 No. 2 tahun 2015.

O'dea, Thomas F, Sosiologi Agama; Suatu Pengantar Awal Jakarta: CV Rajawali, 1992.

Puersen, Van, Strategi Kebudayaan Yogyakarta: Kanisius, 1988.

Ranjabar, Jacobus, Sistem Sosial Budaya Indonesia; Suatu Pengantar Bogor: Ghalia Indonesia, 2006.

Sairin, Sjafri, Perubahan Sosial Masyarakat Indonesia Yogyakarta: Pustaka Pelajar, 2002.

Setiadi, Elly M., Ilmu Sosial Dasar Jakarta: Kencana, 2012.

Leonard Siregar, "Antropologi dan Konsep Kebudayaan", Jurnal Antropologi Papua, Vol. 1, No. 1 Agustus, 2002. 
Soekanto, Soerjono, Sosiologi Suatu Pengantar Jakarta: Raja Grafindo Persada, 2006.

Syam, Nur, Islam Pesisir Yogyakarta: LKIS, 2005.

Victor Turner, Simbol in Ndembu Ritual, in Victor Turner, the Forest of Simbol: Aspect of Ndembu Ritual Ithica: Cornell University Press, 1967.

Widodo, dkk, Kamus Imiah Populer; dilengkapi EYD dan Pembentukan Istilah Yogyakarta: Absolut, 2002.

Woodward, Islam Jawa; Kesakralan Normatif versus Kebatinan Yogyakarta: LKiS, 1999.

\section{Wawancara}

Pertiwi, Wawancara, Bojonegoro, 02 April 2015.

Suto, Wawancara, Bojonegoro, 02April 2015.

Sarkam, Wawancara, Bojonegoro, 01April 2015.

Tulus, Wawancara, Bojonegoro, 02 April 2015.

K. Roqib, Wawancara, Bojonegoro, 07 November 2015.

Hendra, Wawancara, Bojonegoro, 02 April 2015.

Mbah Jo, Wawancara, Bojonegoro, 02 April 2015.

Pembacaan Do'a oleh Modin Mahfud pada 2 April 2015 di Bojonegoro. 